\title{
NOMADLAND: SURVIVING AMERICA IN THE TWENTY-FIRST CENTURY
}

by Jessica Bruder

\section{(A Book Review)}

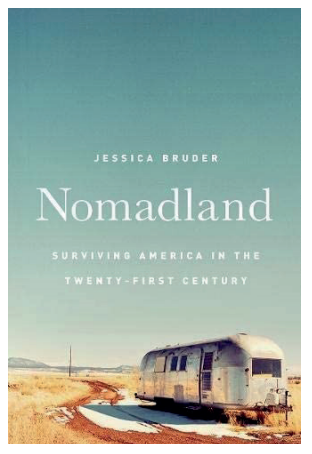

Afoot and light-hearted I take to the open road,

Healthy, free, the world before me,

The long brown path before me leading wherever I choose.

-Walt Whitman

$\bigcup_{t}$ April 21, 2021, the Dolby Theatre held the 93rd Academy Awards ceremony. The event, unusual as the whole 2020-2021 cycle, abounded with surprises. Indisputably, the biggest winner of the night was the film Nomadland directed by Chloé Zhao. The movie won three Oscars: for the Best Actor, the Best Director, and most importantly, the Best Picture. Chloé Zhao became the second woman ever to win the Academy Award for the Best Director and the first woman of color in history to receive it. During her acceptance speech, Chloé Zhao addressed the real-life nomads who inspired both her and Jessica Bruder, the author of the non-fiction book on which the film was based, to tell their story to the public. Thanking her heroes, Zhao emphasized the fact that they taught the writer and the director "the power of resilience and hope" and reminded them "what true kindness looks like" ("Nomadland' Wins Best Picture | 93rd Oscars," 00:02:18-00:03:12).

Jessica Bruder published her book Nomadland: Surviving America in the Twenty-First Century in September of 2017. She introduces 
the readers to the phenomenon of Americans whose lives changed radically in the aftermath of the Great Recession (2007-2009). Job loss, abnormal levels of the outstanding Social Security payments, or simply the ballooning housing costs which would outbalance their earnings-all force them out of their comfort zone which, up to then, they would take for granted. When the crisis hits, many of its victims move out of their houses and adopt a nomadic lifestyle. Vans, buses, and campers become their homes as they travel across the United States, seeking seasonal work and trying to make the most of their lives despite economic impediments, legal obstacles, and ever-present hardships. The central character of Bruder's story is Linda May, an awe-inspiring 64-year-old grandmother, whose trials and tribulations propel her dream of building a sustainable Earthship house. Today, Linda May lives on the road full-time, accompanied by her beloved cavalier spaniel, Coco. Yet, before the Recession forced her into her van, her axis mundi was the couch by the front door of the house that her family rented-a house, which she used to share with her daughter Audra, her son-in-law Collin, and their three teenage children. As a young woman, Linda had studied construction technology, later complementing her income as a cigarette girl at a casino and as a cocktail waitress. Although she had never been afraid of hard work, nor suffered from the lack of ambition, like many people in America, Linda spent her life living from one paycheck to another, unable to amass any significant savings for her retire-

CarCulture(s) Machines, Roads Mythologies ment years. Her Social Security estimates for her retirement amounted to $\$ 500$ a month, a sum making life at a decent level in the US today impossible. Although her needs had always been moderate, Linda would never have expected her retirement years to turn out to be miserable: the home was neither spacious enough nor comfortable for the number of people living in it, and, more importantly, the feeling of being confined to one place without any prospects for the improvement of the situation in any foreseeable future eventually overwhelmed her.

It is a well-known fact that maintaining a house in the United States involves high costs; it is, however, possible to reduce the amount of the monthly payments covering rent and utility bills if a person does not own any property. It is no wonder then 
that workamping became a viable alternative for the Americans hit by the Great Recession, even though, as the epigraph to this review suggests, the very idea of nomadic life in the West is much older. Apart from the traditional migratory cultures of many Indigenous Nations both in Europe and in the Americas, Western nomads have been around for centuries, co-existing with sedentary populations. Sometimes driven by the economy, sometimes by choice, they have become a visible presence all over America, exploring the country from one coast to another. They have been living on the road for generations. In a private message to Jessica Bruder, Don Wheeler, a character featuring in her book under a pseudonym, explains the phenomenon thus:

Workampers are modern mobile travelers who take temporary jobs around the US in exchange for a free campsite-usually including power water, and sewer connections-and perhaps a stipend. You may think that workamping is a modern phenomenon, but we come from a long, long tradition. We followed the Roman legions, sharpening swords and repairing armor. We roamed the new cities of America, fixing clocks and machines, repairing cookware, building stone walls for a penny a foot and all the hard cider we could drink. We followed the emigration west in our wagons with our tools and skills, sharpening knives, fixing anything that was broken, helping clear the land, roof the cabin, plow the fields and bring in the harvest for a meal and pocket money, then moving on to the next job. Our forebears are the tinkers.

We have upgraded the tinker's wagon to a comfortable motor coach or fifth-wheel trailer. Mostly retired now, we have added to our repertoire the skills of a lifetime in business. We can help run your shop, handle the front or back of the house, drive your trucks and forklifts, pick and pack your goods for shipment, fix your machines, coddle your computers and networks, work your beet harvest, landscape your grounds or clean your bathrooms. We are the techno-tinkers. (Bruder 2018: 46-47)

Linda and her workamping companions portrayed in the book exemplify the above description. Modern techno-tinkers' automobiles vary from passenger cars equipped with fittings allowing their drivers to attach tents to the roofs, campervans, and trailers, to school buses transformed into cozy mobile homes, of which many are comfortable enough to spend a whole year in them. Since such vehicles are often fitted with heating systems, solar panels, and satellite dishes, many of the modern techno-nomads may serve their guests freshly ground coffee from their expresso machines, or even offer them room to spend the night on the couch in their 
CarCulture(s) Machines, Roads Mythologies

'living areas.' Yet, although such a description may sound enticing, one must not forget that the 'free life' of a contemporary nomad is far from 'living for free.' Apart from people like Linda, whose health and meager retirement still allows them to live a nomadic life, there are many who struggle to cover the costs of such an existence by seeking temporary jobs wherever and whenever an opportunity arises. Unsurprisingly, the capitalist world, recognizing the dominant economic trends, readily provides solutions, whose ethics, also unsurprisingly, is often questionable.

Jessica Bruder discloses a phenomenon whose scale few 'sedentary' Westerners today care to acknowledge. She opens her readers' eyes to the emergence of an enormous job market tailored specifically to generate profit from the situation which turned former owners or tenants of apartments or houses into contemporary nomads. This market is perhaps best epitomized by Amazon, being one of the companies to first recognize the value of the new niche. Having seen the results of the revision of the company policies accounting for the newly emergent social situation, the Amazon CEO, Jeff Bezos, sadly, was right to predict that "by the year 2020 , one out of every four work campers in the United States will have worked for Amazon." Considering the horrific work conditions imposed by Amazon that Jessica Bruder describes in detail, a 'sedentary' Westerner cannot but wonder how it is possible for the company to not experience problems with recruiting new employees every year. Bruder spares no effort in sharing the opinions of Amazon ex-employees, who overtly speak of a shocking number of hours spent at work and of the shameless hourly rates offered by the company. With meticulous attention to detail, Bruder describes the Amazon Towns, which emerge in the vicinities of the Amazon logistics centers when workampers seeking jobs park their vehicles as close to their workplace as possible, and shares the practical hints that the seasonal inhabitants of the Amazon Towns would impart to those looking for such employment:

Getting prepared both physically and mentally will be the key to you having a successful peak season at Amazon. We cannot stress enough the importance of arriving at Amazon physically prepared. If you've not exercised regularly, consult your physician about a conditioning program, then get active! Here's a low cost suggestion: Get out and walk! Walking is a great form of exercise. It doesn't cost anything and is easier 
on the joints than other forms of exercise. Before setting out, warm up those muscles by stretching. Experts say that as we get older, the collagen structure in our bodies changes, reducing our flexibility and range of motion. (Bruder 2018: 98)

Internet fora abound with recommendations for those considering taking up the job at an Amazon warehouse. Some users advise others to break new shoes before wearing them to work, or buying a good hand care lotion to remedy damage caused by the prolonged use of protective gloves, or soothe cuts or abrasions. Others suggest that a positive attitude towards work should be kept up, remembering that working for Amazon is not a career but a seasonal job. Amazon Towns, in turn, advertise attractions located close to the warehouses, encouraging the workers to enjoy their free time between shifts, and thus putting on the mask of a benign, or even caring, employer, with the view to offsetting the image the company earned by its ruthless exploitation of those whose options are close to none.

Clearly, despite the size and the economic potential of Amazon, recruiting workampers to work for the corporation is of paramount significance; it is important enough for a special program-unambiguously called the CamperForce-to be implemented in order to warrant the influx of cheap labor. Bruder explains how the CamperForce, created especially with the modern nomads in mind, recruits workers during the peak business season-the season before Christmas-and how their work is organized in reality. The shifts, as the writer's interlocutors disclose, are usually ten hours long, and often even longer; the temperature in the warehouse oftentimes reaches as many as 90 degrees Fahrenheit. In this context, a detailed description of the tasks performed at work resembles a description of an Olympic level full-body workout: throughout the duration of the shift, the employee spends ten or more hours walking, stooping, squatting, climbing stairs and ladders, reaching for merchandise located on higher shelves, or carrying heavy loads; each worker is expected to be able to lift packages weighing up to fifty pounds. Why then, Bruder asks, does Amazon hire elderly candidates for the job that seems to be tailored for younger, more fit, individuals? 
The responses vary. For instance, Joanne Johnson, a 57-year-old who missed only one scheduled workday after an accident at work, believes that "[i]t's because we're so dependable. We know that if you commit to something, you do your best to get that job done. We don't take days off unless we have to" (Bruder 2018: 59). Her employers at the CamperForce claim that "older workers bring a good work ethic" (Bruder 2018: 59) and, understanding the true meaning of work, they put their minds into it. The most obvious reason, however, is money:

Amazon reaps federal tax credits-ranging from 25 to 40 percent of wages-for hiring disadvantaged workers in several categories, including aging recipients of Supplemental Security Income (SSI) and anyone on food stamps. Savvy CamperForce members know all about that incentive. "The Work Opportunity Tax Credit is the reason Amazon can take on such a slow, inefficient workforce," noted one itinerant worker on her blog, Tales from the Rampage. "Since they are getting us off government assistance for almost three months of the year, we are a tax deduction for them." (Bruder 2018: 59)

Even without any profound knowledge of the economic history of the United States it is possible to a identify a rather clear pattern of the recurrence of the modern-world nomadism in the West. Jessica Bruder reminds her readers that in the mid-1930s, when America was still in the grip of the Great Depression, house trailers were produced en masse because the producers discovered that mobile homes could serve far more serious purposes

CarCulture(s) Machines, Roads Mythologies than solely that of an extravagant vacation. Not unlike during the Great Recession, also in the 1930 s moving into a trailer would allow those in dire straits to cut costs of rent and householding expenses (Bruder 2018: 59). A New York Times Magazine columnist confirms it, stating that in 1936 "[the United States was] rapidly becoming a nation on wheels" (Miller 1936: N20). One year later, Konrad Bercovici reiterates this diagnosis in his Harper's Magazine, article claiming that campers represent "a new way of life which will eventually change our architecture, our morals, our laws, our industrial system, and our system of taxation" (Bercovici 1937: 621). Emphasizing the parallels between the socioeconomic transformations of the two periods of crisis, Bruder describes how Bob Wells, one of the most famous vandwellers, the owner 
of the website CheapRVLiving.com, communicated his moral vision of the situation to those most severely affected by the Great Recession of 2007-2009:

After the financial meltdown of 2008, traffic to CheapRVLiving.com exploded. "I started getting emails almost daily from people who had lost their jobs, their savings were running out, and they were facing foreclosure on their home," he later wrote. Cast out of the middle class, these readers were trying to learn how to survive. Googling phrases such as "budget living" and "living in a car or van" brought them to Bob's website. And in a culture where economic misfortune was blamed largely on its victims, Bob offered them encouragement instead of opprobrium. "At one time there was a social contract that if you played by the rules (went to school, got a job, and worked hard) everything would be fine," he told readers. "That's no longer true today. You can do everything right, just the way society wants you to do it, and still end up broke, alone, and homeless." By moving into vans and other vehicles, he suggested, people could become conscientious objectors to the system that had failed them. They could be reborn into lives of freedom and adventure. (Bruder 2018: 74)

As if disregarding the most profound reasons for the rebirth of nomadism in America, in 2011 The New York Times Magazine published the article which proudly stated that "living in a van [...] is now fashionable" (Spitznagel 2011: 9). The cold irony of such PR obviously borders on cruel cynicism: both periods of crisis demonstrate beyond doubt that it is only when a financial crisis of massive proportions hits the social groups whose annual income is below average that modern nomadism skyrockets. The scale of the phenomenon demonstrates that 'fashion' is the least important of all factors when the impermanence, instability, and dangers of the 'life on wheels' become the only alternative to bankruptcy and, ultimately, to homelessness. And though the Great Recession is now history, the latest global crisis caused by the Covid-19 pandemic is more than likely to produce a similar outcome (Spitznagel 2011: 9). The Covid-19 recession has run a number of industries to the ground, resulting in the loss of income for their employees. Without stable earnings, thousands lost their financial liquidity. Unable to pay their rent, and aware that the inhuman housing market will not be merciful, they come to realize yet again that sometimes the only right choice to make is to become houseless, rather than homeless. Meanwhile, during 
the Covid-19 pandemic, Jeff Bezos's fortune skyrocketed to \$24 billion (Evelyn 2020). Predictably, a new wave of the cynical PR heralding the return of the fashion of 'living in a van' will ensue. And some will, inevitably, believe that most of those who choose such a life light-heartedly 'take to the open road.' 
Bercovici, Konrad. "Gypsy in a Trailer [Part I]." Harper's Magazine, May 1937, p. 621.

Bruder, Jessica. Nomadland: Surviving America in the Twenty-First Century. W.W. Norton, 2018, pp. 46-47.

Evelyn, Kenya. "Amazon CEO Jeff Bezos grows fortune by \$24bn amid coronavirus pandemic." The Guardian, April 15, 2020. https:// www.theguardian.com/technology/2020/apr/15/amazonjeff-bezos-gains-24bn-coronavirus-pandemic. Accessed 4 May 2021.

Miller, Clyde R. "Trailer Life Seen as Good for Nation, Aiding Instead of Displacing Homes." The New York Times, December 20, 1936, p. N2.

Spitznagel, Eric. "What the Kids Are Doing These Days." The New York Times Magazine, November 6, 2011, p. 9.

Whitman, Walt. "Song of the Open Road." Leaves of Grass, Harper Collins Publishers, 2015.

"Nomadland" Wins Best Picture | 93rd Oscars YouTube, uploaded by Oscars, 2 June, 2021, https://youtu.be/t1hkWbhhga8. Accessed 10 Jun. 2021. 
